\title{
2-Hydroxynaphthoquinones. Synthesis, electrochemical study, and biological essays of activity
}

\author{
César R. Solorio-Alvarado, ${ }^{a *}$ Eduardo Peña-Cabrera, ${ }^{a *}$ Jesús García-Soto,${ }^{b}$ Juana López- \\ Godínez, ${ }^{b}$ Felipe J. González, ${ }^{c}$ and Alejandro Álvarez-Hernández. ${ }^{\text {d }}$ \\ ${ }^{a}$ Facultad de Química. Universidad de Guanjuato, Col. Noria Alta S/N. Guanajuato, GTO. \\ México 36050 \\ ${ }^{b}$ Instituto de Investigaciones en Biología Experimental. Universidad de Guanjuato, Col. Noria \\ Alta S/N. Guanajuato, GTO. México 36050 \\ ${ }^{c}$ Departamento de Química, Centro de Investigacion y Estudios Avanzados del I.P.N, México \\ D.F. 07360 \\ ${ }^{d}$ Centro de Investigaciones Químicas, Universidad Autónoma del Estado de Hidalgo. Carretera \\ Pachuca-Tulancingo Km. 4.5. Cd. Universitaria, Mineral de la Reforma, Hidalgo, 42076 Mexico \\ E-mail:eduardop@quijote.ugto.mx; crsolorio@iciq.es
}

\begin{abstract}
The synthesis of nine 2-hydroxynaphthoquinones was achieved starting from squaric acid esters. The electrochemical and biological evaluations of these compounds were tested using the sea urchin ovules as a model. An interesting correlation between structure and activity was observed, as well as the possibility to predict the substitution patterns of new related active molecules.
\end{abstract}

Keywords: Squaric esters, naphthoquinones, cancer, radical anion

\section{Introduction}

Naphthoquinoid compounds play an important role as biologically active molecules. Their importance, ${ }^{1}$ characteristics, and electronic properties ${ }^{2,3}$ have been widely documented. We can mention their occurrence in the mitochondria, their involvement in processes of cellular respiration, ${ }^{4}$ in some plants giving them color, or even in human beings in such important molecules as vitamins. In medicine, the naphthoquinone nucleus is outstanding because of its antiviral, ${ }^{5}$ fungitoxic, ${ }^{6,7}$ bactericide, ${ }^{8,9}$ antiparasitary, ${ }^{10,11}$ antiinflamatory ${ }^{12,13}$ and anti-HIV ${ }^{14}$ activities, among others.

Some examples of these types of molecules are illustrated in Figure 1. 


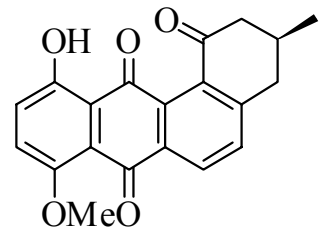

$(+)$-Hatomarubigin B

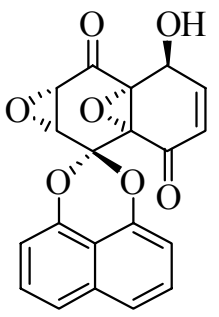

Diepoxin $\sigma$

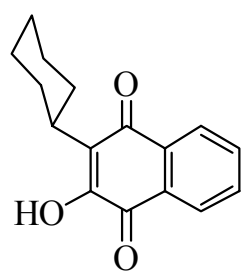

Parvaquone

Figure 1. Examples of naturally-occurring quinones.

Similarly, a special subgroup of these compounds is constituted by 2hydroxynapthoquinones, whose presence as naturally occurring compounds, ${ }^{15}$ and their role as drugs against parasitosis ${ }^{16}$ have been well described. The quinoid moiety is well known by its electronic properties. It is considered as a component of biological electron transfer chains located in the membranes of mitochondria, bacteria and chloroplasts. Depending on their molecular structure, some quinones can be used as vitamins or drugs. ${ }^{17}$

It is also recognized that when the quinoid ring is substituted by an appropriate alkyl chain, these compounds can exhibit anticancer and antitumor activity. ${ }^{18}$ Therefore, the naphthoquinoid ring, is an important target not only in total synthesis, but also to study its electrochemical and redox properties to correlate these with its biological activity.

\section{Results and Discussion}

The synthesis of a family of 2-hydroxynaphthoquinones with different substitution patterns is described. Additionally, we carried out the electrochemical study of these molecules with the purpose of determining their redox potentials and their possible correlation with their biological activity. Biological essays will be described in the last part of this work.

\section{Synthesis}

Nine 2-hydroxylnaphthoquinones were synthesized. Different substituents at the six-position were incorporated in order to have structural variety, and to try to establish a structure-activity correlation in the biological essays. The squaric acid ester chemistry, developed mainly by Liebeskind and Moore, ${ }^{19}$ was utilized for the preparation of the different derivatives. Thus, a family of nine naphthoquinones was synthesized (Figure 2). 


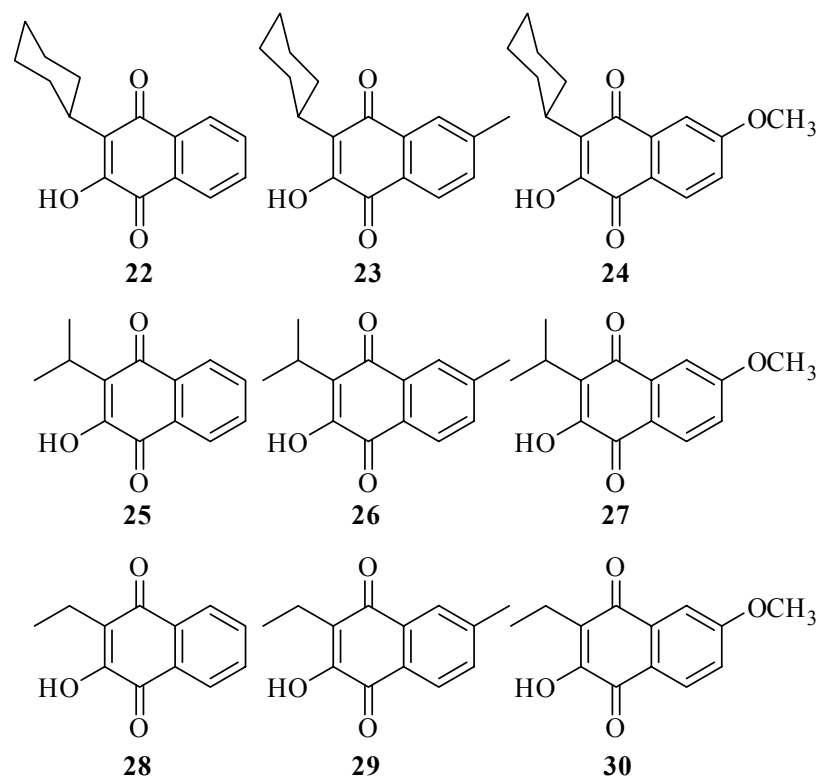

Figure 2. Naphthoquinones synthesized in this work.

The retrosynthetic analysis was envisioned as illustrated in Scheme 1.<smiles>[R]C=Cc1ccc2c(c1)C(=O)C([R])=C(OC(C)C)C2=O</smiles>

\section{Scheme 1}

We began by preparing alkyl-substituted squaric esters derivatives 1-3 (Scheme 2).

These starting materials were prepared by addition of corresponding Grignard reagents at $-78{ }^{\circ} \mathrm{C}$, to diisopropylsquarate. From this point on, two different routes were followed to obtain the desired compounds. The first route involved quenching with aq. $\mathrm{NH}_{4} \mathrm{Cl}$ followed acid-catalyzed rearrangement of the crude material. In the second route, the alkoxide that resulted from the Grignard addition was quenched directly at low temperature with trifluoroacetic anhydride (TFAA) to give directly $\mathbf{1 - 3}$. The corresponding yields are reported in Table 1.

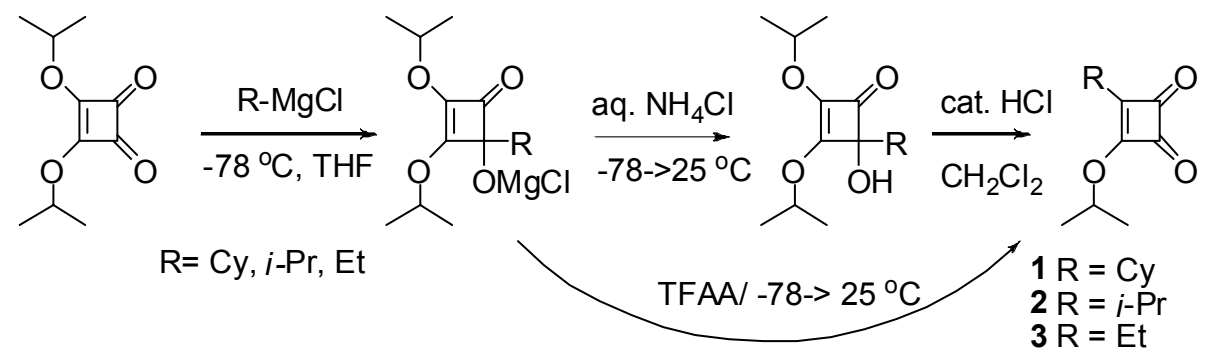

\section{Scheme 2}


Table 1. Different reaction conditions for the preparation of 1-3

\begin{tabular}{ccc}
\hline Product & $\begin{array}{c}\text { \% yield after aq. } \\
\mathrm{NH}_{4} \mathrm{Cl} / \mathrm{HCl} \\
\text { treatment }\end{array}$ & $\begin{array}{c}\text { \% yield after } \\
\text { TFAA } \\
\text { treatment }\end{array}$ \\
\hline $\mathbf{1}$ & 68 & 93 \\
$\mathbf{2}$ & 92 & 75 \\
$\mathbf{3}$ & 56 & 80 \\
\hline
\end{tabular}

It can be concluded from Table 1 that direct treatment with TFAA is somewhat more efficient and practical than the two-step method. Next, adducts 4-12 were obtained after addition of the corresponding aryllithium derivatives followed by aqueous quench. Thus, low-temperature addition of phenyl, $p$-tolyl and $p$-methoxyphenyllithium derivatives (generated by metal-halogen exchange of the corresponding iodides) to the more electrophilic carbonyl group of 1-3, gave the expected products. ${ }^{20,21}$ (Scheme 3).

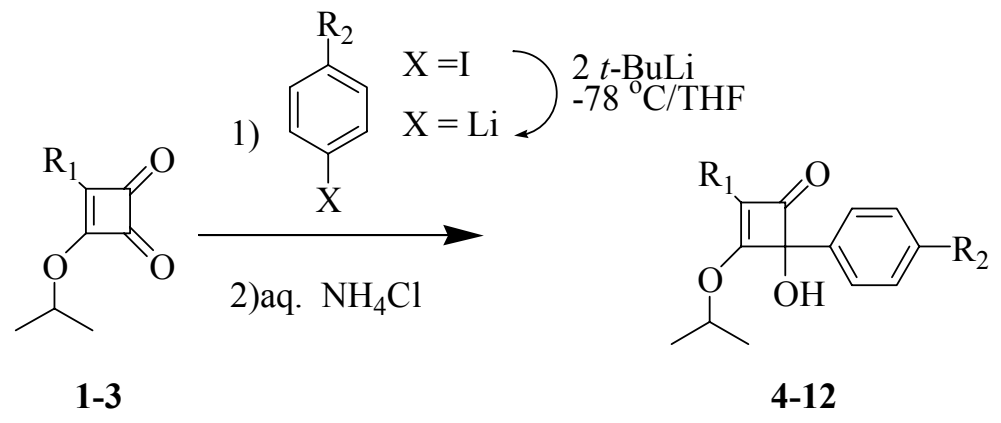

\section{Scheme 3}

The results are shown in Table 2 .

Table 2. Isolated yields of adducts 4-12

\begin{tabular}{cccc}
\hline Adduct & $\mathrm{R}_{1}$ & $\mathrm{R}_{2}$ & \% Isolated yield \\
\hline $\mathbf{4}$ & $\mathrm{Cy}$ & $\mathrm{H}$ & 44 \\
$\mathbf{5}$ & $\mathrm{Cy}$ & $\mathrm{Me}$ & 42 \\
$\mathbf{6}$ & $\mathrm{Cy}$ & $\mathrm{MeO}$ & 34 \\
$\mathbf{7}$ & $i-\mathrm{Pr}$ & $\mathrm{H}$ & 48 \\
$\mathbf{8}$ & $i-\mathrm{Pr}$ & $\mathrm{Me}$ & 23 \\
$\mathbf{9}$ & $i-\mathrm{Pr}$ & $\mathrm{MeO}$ & 63 \\
$\mathbf{1 0}$ & $\mathrm{Et}$ & $\mathrm{H}$ & 42 \\
$\mathbf{1 1}$ & $\mathrm{Et}$ & $\mathrm{Me}$ & 42 \\
$\mathbf{1 2}$ & $\mathrm{Et}$ & $\mathrm{MeO}$ & 44 \\
\hline
\end{tabular}


Despite the fact that the additions shown in Scheme 3 were clean by TLC, the adducts 4-12 were somewhat unstable to chromatography conditions on silica-gel, even in the presence of $1 \%$ triethylamine in the eluent. Remarkably, nucleophilic additions on cyclohexyl derivative 1, were faster than on 2 and even faster than on 3. Having adducts 4-12 in hand, ring-opening and concomitant cyclization were carried out by thermolysis of the neat compounds at $160{ }^{\circ} \mathrm{C}$ for 5 min to obtain the corresponding dihydroxynaphthalenes. On exposure to air, these derivatives yielded directly naphthoquinones 13-21 in high yields as illustrated in Table 3.

Table 3. Isolated yields of naphthoquinones 13-21

\begin{tabular}{cccc} 
Naphthoquinone & $\mathrm{R}_{1}$ & $\mathrm{R}_{2}$ & $\begin{array}{c}\text { \% Isolated } \\
\text { yield }\end{array}$ \\
\hline $\mathbf{1 3}$ & $\mathrm{Cy}$ & $\mathrm{H}$ & 78 \\
$\mathbf{1 4}$ & $\mathrm{Cy}$ & $\mathrm{Me}$ & 74 \\
$\mathbf{1 5}$ & $\mathrm{Cy}$ & $\mathrm{MeO}$ & 76 \\
$\mathbf{1 6}$ & $i-\mathrm{Pr}$ & $\mathrm{H}$ & 74 \\
$\mathbf{1 7}$ & $i-\mathrm{Pr}$ & $\mathrm{Me}$ & 72 \\
$\mathbf{1 8}$ & $i-\mathrm{Pr}$ & $\mathrm{MeO}$ & 71 \\
$\mathbf{1 9}$ & $\mathrm{Et}$ & $\mathrm{H}$ & 75 \\
$\mathbf{2 0}$ & $\mathrm{Et}$ & $\mathrm{Me}$ & 75 \\
$\mathbf{2 1}$ & $\mathrm{Et}$ & $\mathrm{MeO}$ & 70 \\
\hline
\end{tabular}

The final step of the synthetic sequence consisted of the deprotection of the hydroxyl group of naphthoquinones 13-21. This transformation was achieved by exposing the $i$-Pr- protected naphthoquinones to $\mathrm{BBr}_{3}$ in $\mathrm{CH}_{2} \mathrm{Cl}_{2}$ at low temperature, followed by aqueous quench (Table 4). The resulting hydroxyl-substituted naphthoquinones 22-30 were obtained in good to excellent yields. 
Table 4. Deprotection of naphthoquinones 22-30

\begin{tabular}{cccc} 
& & & \\
\hline & & & \\
Hydroxynaph- & $\mathrm{R}_{1}$ & $\mathrm{R}_{2}$ & Isolated \\
thoquinone & & & yield \\
\hline $\mathbf{2 2}$ & & $\mathrm{H}$ & 82 \\
$\mathbf{2 3}$ & $\mathrm{Cy}$ & $\mathrm{Me}$ & 92 \\
$\mathbf{2 4}$ & $\mathrm{Cy}$ & $\mathrm{MeO}$ & 84 \\
$\mathbf{2 5}$ & $\mathrm{Cy}$ & $\mathrm{H}$ & 81 \\
$\mathbf{2 6}$ & $i$-Pr & $\mathrm{Me}$ & 78 \\
$\mathbf{2 7}$ & $i$-Pr & $\mathrm{MeO}$ & 81 \\
$\mathbf{2 8}$ & $\mathrm{-Pr}$ & $\mathrm{H}$ & 81 \\
$\mathbf{2 9}$ & $\mathrm{Et}$ & $\mathrm{Me}$ & 91 \\
$\mathbf{3 0}$ & $\mathrm{Et}$ & $\mathrm{MeO}$ & 79 \\
\hline
\end{tabular}

It is important to mention that in 6-OMe series $(\mathbf{2 4}, \mathbf{2 7}$, and 30), only the i-Pr-protected hydroxyl group reacted, leaving intact the Me-protected hydroxyl group as evidenced by singlets at 3.96, 3.94, and $3.95 \mathrm{ppm}$ (3H's each) respectively, in the ${ }^{1} \mathrm{H}$ NMR spectra.

This methodology represents a very convenient way to selectively deprotect hydroxyl groups in these substrates, depending upon the alkyl group used to protect them.

\section{Elecrochemical Study}

The electrochemical study of compounds 22-30 was carried out by cyclic voltammetry in acetonitrile on glassy carbon electrodes. The voltammometric behavior was similar in all the cases and it is shown in Figure 3A for the case of parvaquone (22). 


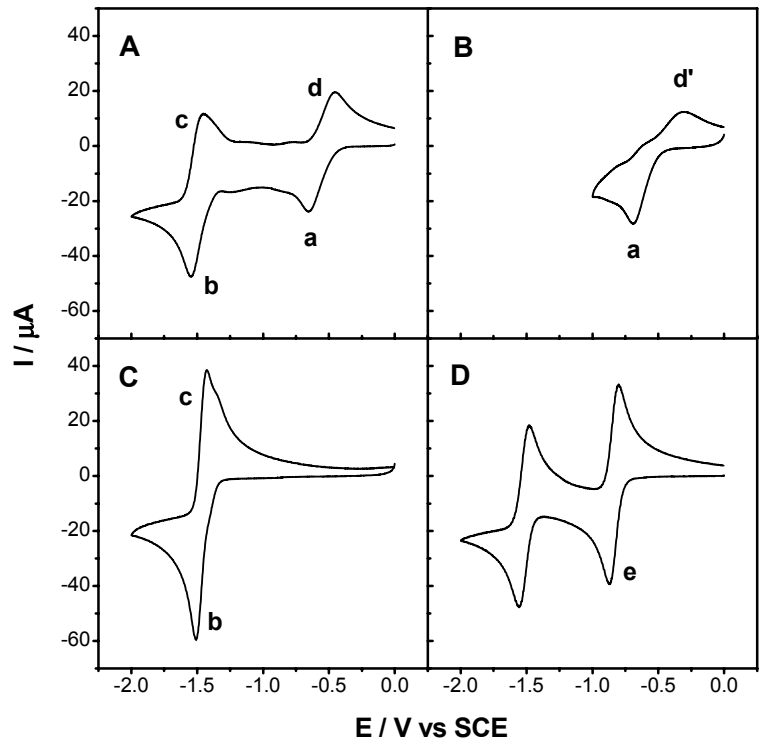

Figure 3. Cyclic voltammetry of compound 22, $2 \mathrm{mM}$ in acetonitrile $+0.1 \mathrm{M} n-\mathrm{Bu}_{4} \mathrm{NPF}_{6}$ on glassy carbon electrode $(3 \mathrm{~mm} \phi)$ at $0.1 \mathrm{Vs}^{-1}$. A) Compund 22 until a reverse potential of $-2 \mathrm{~V}$ vs $\mathrm{SCE}$. B) Compound 22 until a reverse potential of $-1 \mathrm{~V}$ vs SCE. C) Compound $22+n-\mathrm{Bu}_{4} \mathrm{NOH}$ $2 \mathrm{mM}$. D) Methoxylated parvaquone $2 \mathrm{mM}$.

In agreement with the behavior previously reported for other kind of hydroxyl-substituted quinones, ${ }^{22}$ the voltammogram of parvaquone correspond to an overall reduction process involving self-protonation reactions, as depicted in Scheme 4, where QH represents any of the hydroxyl-compounds 22-30, possessing an acidic strength dependant on the substituent nature.

$$
\begin{aligned}
& \mathrm{QH}+\mathrm{e}^{-} \rightleftharpoons \mathrm{QH}^{\cdot-} \\
& \mathrm{QH}^{--}+\mathrm{QH} \rightleftharpoons \mathrm{QH}_{2}^{\cdot}+\mathrm{Q}^{-} \\
& \mathrm{QH}_{2}^{\cdot}+\mathrm{e}^{-} \rightleftharpoons \mathrm{QH}_{2}^{-} \\
& \text {and/or } \\
& \mathrm{QH}_{2}^{\cdot}+\mathrm{QH}^{-} \rightleftharpoons \mathrm{QH}_{2}^{-}+\mathrm{QH} \\
& \mathrm{QH}_{2}^{-}+\mathrm{QH} \rightleftharpoons \mathrm{QH}_{3}+\mathrm{Q}^{-} \\
& \mathrm{QH}^{+} 2 / 3 \mathrm{e}^{-}=1 / 3 \mathrm{QH}_{3}+2 / 3 \mathrm{Q}^{-}
\end{aligned}
$$

\section{Scheme 4}


In the framework of this mechanism, the initial reduction step occurs at the level of signal "a" affording the radical anion $\mathrm{QH}^{-}$(eq 1). This species is rapidly protonated by the neutral $\mathrm{QH}$ molecule, giving rise to the protonated radical $\mathrm{QH}^{\cdot}$ and the conjugated base $\mathrm{Q}^{-}$(eq 2).

This father-son reaction confers the chemically irreversible character to wave "a", as illustrated in Figure 3B, from the cathodic to anodic peak potential separation $(>350 \mathrm{mV})$. Owing to the fact that $\mathrm{QH}^{\cdot}$ is easier to reduce than $\mathrm{QH}$, the second electron transfer can occurs heterogeneously (eq 3) and/or homogenously by disproportionation (eq 3') to produce $\mathrm{QH}_{2}{ }^{-}$. Finally, a second self-protonation reaction occurs to generate the corresponding hydroquinone structure $\mathrm{QH}_{3}$ (eq 4). Thus, the overall reduction process occurring at the level of wave "a" is represented by eq 5 , and it presents an electronic stoichiometry of $2 / 3$.

In order to confirm that the electron number of wave "a" in Figures 3A-B corresponds to 2/3, the voltammogram of a new molecule was obtained in which the $\mathrm{OH}$ group in parvaquone 22 was replaced by the methoxy group (Figure 3D). In this way, the self-protonation processes are suppressed and the figure shows only two consecutive one-electron reversible processes, which represent the typical behavior of quinones in aprotic medium. ${ }^{22}$

In this figure the first wave represents the passage from the quinone to a radical anion and the second wave represents the passage from the radical anion to a dianion. Thus, by comparing the peak current of wave "a" in Figure 3A $(23.9 \mu \mathrm{A})$ and the peak current of wave "e" in Figure 3D $(38.7 \mu \mathrm{A})$, it is obtained that the experimental electron number of 0.62 is close to the electronic stoichiometry of $2 / 3$ predicted by Scheme 4 .

According to eq 5, the reaction products are the hydroquinones in form of $\mathrm{QH}_{3}$ and the conjugated base $\mathrm{Q}^{-}$, which are related respectively to the oxidation wave "d" in Figures $3 \mathrm{~A}$ and $3 \mathrm{~B}$ and the reduction wave " $\mathrm{b}$ " in Figures $3 \mathrm{~A}$ and $3 \mathrm{C}$.

From the point of view of single electron and proton transfer, the oxidation process of $\mathrm{QH}_{3}$ is not evident and it can be even more complicated if we consider that hydrogen bonding association can occur with the conjugated base Q-. That is why the position of wave "d" in Figure and $3 \mathrm{~B}$ is dependant on the reverse potential. With respect to the species $\mathrm{Q}^{-}$, it can be formed ex-situ by stoichiometric neutralization of $\mathrm{QH}$ with tetrabutylammonium hydroxide. ${ }^{23}$

Figure $3 \mathrm{C}$ shows the voltammogram of pure $\mathrm{Q}^{-}$, where the signals " $\mathrm{b}-\mathrm{c}$ " are similar to the corresponding signals in Figure. In both figures the reversible nature of wave "b-c" is related to the formation of a stable 0ianion, whose radical nature has been demonstrated recently by EPR measurements (eq 6). ${ }^{24}$

$$
\mathrm{Q}+\mathrm{e} \rightleftharpoons \mathrm{Q}^{2-}
$$

Table 5 summarizes the principal potential data obtained from the voltammometric experiments carried out with compounds 22-30. Owing to the chemically irreversible nature of wave "a", as shown in Figure 3B, only the peak potential at $0.1 \mathrm{Vs}^{-1}$ was considered for this signal. In the case of wave "b-c", it was considered the redox potential $\mathrm{E}_{1 / 2}$. 
Table 5. Electrochemical parameters of hydroxynaphthoquinones 22-30.

\begin{tabular}{cccc}
\hline $\begin{array}{c}\text { Hydroxynaph- } \\
\text { toquinone }\end{array}$ & $\begin{array}{c}\mathrm{E}_{\mathrm{p}} \text { "a" } \\
\text { V/SCE }\end{array}$ & $\begin{array}{c}\mathrm{E}_{\mathrm{p}} \text { "d" } \\
\text { V / SCE }\end{array}$ & $\begin{array}{c}\mathrm{E}_{1 / 2} \text { "b- } \\
\text { c" } \\
\mathrm{V} / \mathrm{SCE}\end{array}$ \\
\hline $\mathbf{2 2}$ & -0.681 & -0.423 & -1.451 \\
$\mathbf{2 3}$ & -0.719 & -0.482 & -1.562 \\
$\mathbf{2 4}$ & -0.733 & -0.486 & -1.576 \\
$\mathbf{2 5}$ & -0.731 & -0.363 & -1.529 \\
$\mathbf{2 6}$ & -0.728 & -0.453 & -1.547 \\
$\mathbf{2 7}$ & -0.746 & -0.487 & -1.589 \\
$\mathbf{2 8}$ & -0.647 & -0.421 & -1.497 \\
$\mathbf{2 9}$ & -0.668 & -0.415 & -1.435 \\
$\mathbf{3 0}$ & -0.701 & -0.441 & -1.408 \\
\hline
\end{tabular}

Table 5 shows that the reduction peak potential of wave "a", as well as the half-wave potential of the reversible signal " $b-c$ " is dependant on the substituent nature. Accordingly to previous work, ${ }^{22}$ in the series $\mathbf{2 2 - 2 4}$ and $\mathbf{2 5 - 2 7}$, it is observed that the higher the electron releasing character of the substituent, the lower the peak potential of reduction.

On the other hand, due to the fact that the values of peak potential are dependent on the rate of the first self-protonation reaction, it can be considered that the values of the half-wave potential of the reversible wave "b-c" could be the better choice to look for a correlation with data of biological activity.

\section{Biological assays of activity}

The embryo is a good model to test the effect of different drugs, specifically those targeted to affect cell division. Sea urchine embryos have been used to test the effect of chemical substances on its development. ${ }^{25}$

The advantage of this approach is that since the fertilization is external, the embryo will grow in the sea environment, making it easy to manipulate.

Thus, to prove the possible effect of some chemical on cell division, the ovules are preincubated with that compound, fertilized and analyzed under the microscope to evaluate if cellular division occurred.

The following methodology consisted in incubating 2000 ovules with each hydroxynaphthoquinone synthesized 22-30. Concentrations of 200,150,100, 50, 20 and $10 \mu M$ of the drug in DMSO were tested. At the same time, DMSO was used as control. The fertilization is determined by the viteline layer formed around the ovule (Figure 4). 


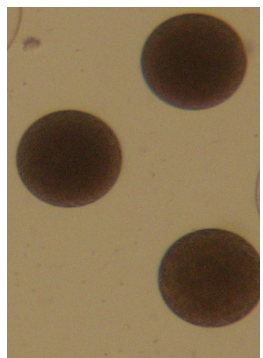

A

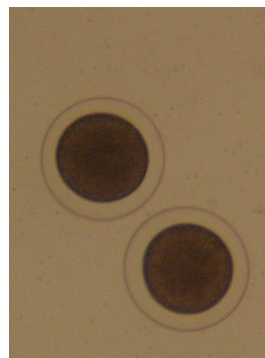

B

Figure 4. A) Non fertilized and B) Fertilized egg of Sea Urchin Stongylocentrotus purpuratus.

A

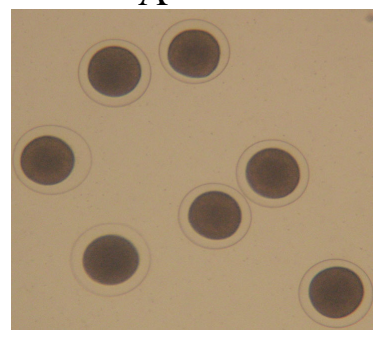

B

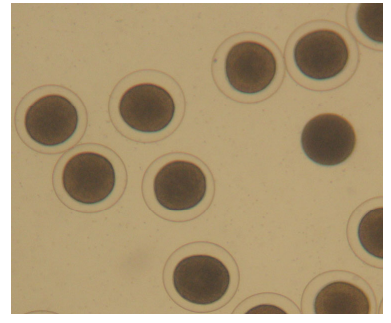

$\mathrm{C}$

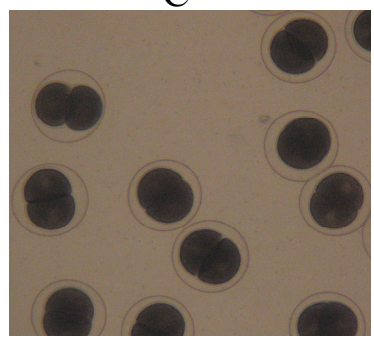

$\mathrm{D}$

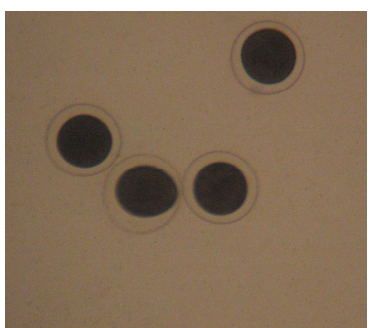

Figure 5. Picture showing ovules fertilized in absence (A) and in the presence (B) of hydroxynaphthoquinone $22(10 \mu \mathrm{M})$. The first cell division was observed after $90 \mathrm{~min}$ of post fertilization in the absence of the quinone (C), and none was observed in the presence of it (D).

Figure 5 indicates that hydroxynaphthoquinone $22(10 \mu \mathrm{M})$ does not affect the formation of the layer of fertilization of the sea urchin egg. Nevertheless, after 90 minutes postfertilization the first cellular division does not appear. This effect was observed with all quinones tested. It was then decided to test concentrations between $0.01-10 \mu M$ to determine $\mathrm{LD}_{50}$ and the IMC (inhibitory minimum concentration). We were able to determine the inhibitory effect and its corresponding $\mathrm{LD}_{50}$. Figure 6 and Table 6 show the results. 
INHIBITORY EFFECT OF THE NINE SYNTHESIZED

NAPHTHOUINONES

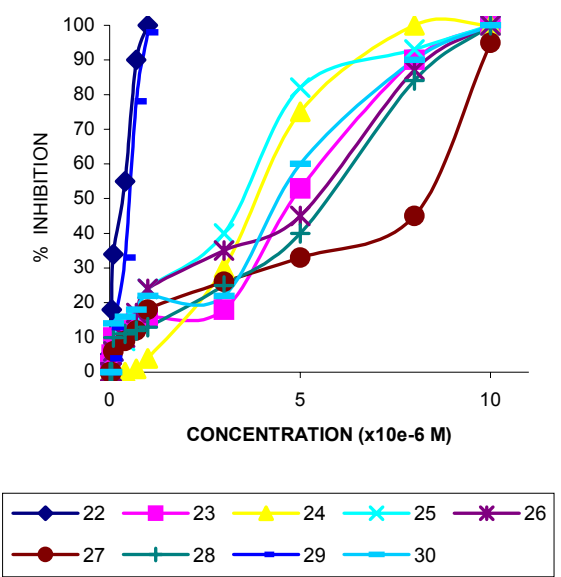

Figure 6. Inhibitory effect observed in the first cell division of fertilized ovules of the nine naphthoquinones synthesized.

Table 6. $\mathrm{LD}_{50}$ of hydroxynaphthoquinones 22-30

\begin{tabular}{cc}
\hline Hydroxynaphthoquinone & $\mathrm{LD}_{50}(\mu \mathrm{M})$ \\
\hline $\mathbf{2 2}$ & $\mathbf{0 . 3 1}$ \\
$\mathbf{2 3}$ & 4.90 \\
$\mathbf{2 4}$ & 3.61 \\
$\mathbf{2 5}$ & 3.55 \\
$\mathbf{2 6}$ & 5.33 \\
$\mathbf{2 7}$ & 7.35 \\
$\mathbf{2 8}$ & 3.00 \\
$\mathbf{2 9}$ & $\mathbf{0 . 4 9}$ \\
$\mathbf{3 0}$ & 3.00 \\
\hline
\end{tabular}

Figure 6 shows that the most active compounds are 22 and 29. The rest of naphthoquinones have similar activity with exception of $\mathbf{2 7}$, which has the lowest effect. The $\mathrm{LD}_{50}$ was determined by examining under microscope when all of ovules were fecundated and only $50 \%$ of them began cellular division (Table 6).

By plotting the data of $\mathrm{LD}_{50}$ with respect to the potential data shown in Table 6, it can be appreciated that high biological activity is related with low reduction potentials of the hydroxynaphthoquinones, similarly, a low activity is related with a high reduction potential.

Figure 7 is the graphical representation of the good correlation between the biological activity and the half-wave potential of the redox process $\mathrm{Q}^{-} / \mathrm{Q}^{2-}$, which can not present coupled protonation reactions under the interfase conditions. From other point of view and taking the 
parvaquone series (22-24), it can be also mentioned that electron-releasing substituents at the 6position disfavor the biological activity.

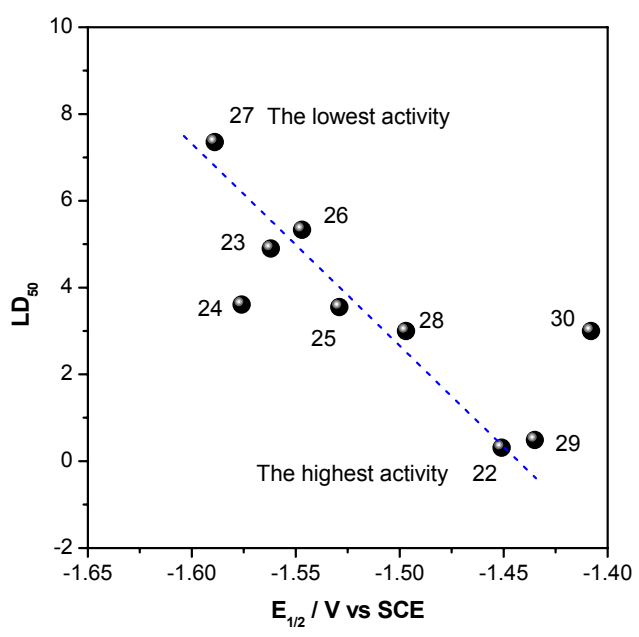

Figure 7. Correlation between $\mathrm{LD}_{50}$ and the $\mathrm{E}_{1 / 2}$ of the redox couple $\mathrm{Q}^{-} / \mathrm{Q}^{.2-}$

Strictly, the same correlation by using the peak potential of signal "a" is not very good, and as it was mentioned before, it could be due to the fact that these peak potentials depend on the rate of self-protonation. A single example of this lack of good agreement is compound 28, because this compound should be the more active if the peak potential is taken as reference ($0.647 \mathrm{~V}$ vs SCE).

\section{Conclusions}

We were able to synthesize a family of nine 2-hydroxylnaphthoquinones. The method is efficient and allowed a structural variety on both rings of the naphthoquinoid moiety. The electrochemistry of 2-hydroxynaphthoquinones 22-30 $(\mathrm{QH})$ reveals that they are reduced following a scheme of electron-transfer and self-protonation reactions. The overall mechanism of reaction involves a $2 / 3$ electronic stoichiometry and the reaction products are the hydroquinone form $\mathrm{QH} 3$ and the conjugated base of each $\mathrm{QH}$ molecule $\left(\mathrm{Q}^{-}\right)$.

It is shown that the increase of the electron-releasing character of the substituents on the 6position in the aromatic nucleus of 22-30 shifts the reduction potential towards more negative values. On the other hand, the introduction of bulky groups on the 3-position in the quinone nucleus shifts the reduction potentials toward less negative values. The competition between these two factors determines essentially the reduction potentials and the biological activity. Owing to the fact that the oxidation potential at the level of the first reduction wave "a" is dependant on the self-protonation reactions, the best correlation with biological activity could be 
concerned with the redox potential of the couple $\mathrm{Q}^{-} / \mathrm{Q}^{\cdot 2-}$, which corresponds to the reversible wave "b-c".

Specifically, we can predict that a bulky group at 3-position and electron-withdrawing group at 6-position in the 2-hydroxylated naphthoquinone, would have the highest biological activity.

\section{Experimental Section}

General Procedures. ${ }^{1} \mathrm{H}$ NMR spectra were recorded on a Varian Gemini $200(200 \mathrm{MHz})$ in deuteriochloroform $\left(\mathrm{CDCl}_{3}\right)$ with either tetramethylsilane (TMS) $(0.0 \mathrm{ppm})$ or chloroform (7.26 ppm) as internal reference unless otherwise indicated. Data are reported in the following order: chemical shift in ppm $(\delta)$, multiplicities (br (broadened)), s (singlet), d (doublet), $\mathrm{t}$ (triplet), $\mathrm{q}$ (quartet), sex (sextet), hep (heptet), m (multiplet), exch (exchangeable), app (apparent), coupling constants, $J$, are reported $(\mathrm{Hz})$, and integration. Infrared spectra were recorded on a Perkin-Elmer FTRI 1600 series spectrophotometer. Peaks are reported $\left(\mathrm{cm}^{-1}\right)$ with the following relative intensities: s (strong 67-100 \%), m (medium 40-67 \%), and w (weak 20-40\%).

Analytical thin-layer chromatography was performed on Merck silica gel plates with F-254 indicator. Visualization was accomplished by UV-light, iodine or $p$-anisaldehyde solution. THF was dried over sodium and stored over activated $4 \AA$ molecular sieves. All reactions were performed under a dry $\mathrm{N}_{2}$ atmosphere in oven- or flame-dried glassware.

Accurate mass spectra were obtained on a Bruker microTOF fitted with an ESI.

Commercial chemicals. The following materials were obtained from commercial sources: $\mathrm{C}_{6} \mathrm{H}_{11} \mathrm{MgCl}$, PhLi, EtMgCl, $i$-PrMgCl, TFAA and $\mathrm{BBr}_{3}, n-\mathrm{Bu}_{4} \mathrm{PF}_{6}$, instant ocean salts. Compounds 1, 4, 13, 22 ${ }^{20}$ and 5-6, 14-15, 23-24 ${ }^{21}$ were prepared as reported in the literature.

\section{Representative synthesis of alkyl squarate derivatives. Rearrangement with TFAA.}

3-Isopropyl-4-isopropoxy-3-cyclobutene-1,2-dione (2). Isopropylmagnesium chloride $(9.25 \mathrm{~mL}$, of a $1.2 \mathrm{M}$ solution, $11.1 \mathrm{mmol})$ was added via syringe to $10 \mathrm{~mL}$ of a cold solution ($\left.78{ }^{\circ} \mathrm{C}\right)$ of diisopropylsquarate $(2.0 \mathrm{~g}, 10.1 \mathrm{mmol}, 1.1 \mathrm{eq})$ in THF. After $20 \mathrm{~min}$ TFAA $(3.3 \mathrm{~mL}$, $20.2 \mathrm{mmol}$ ) was added at the same temperature via syringe, $5 \mathrm{~min}$. later TLC shows the completion of the reaction, the cooling bath was removed and allowed to reach room temperature. The crude reaction mixture was washed with water $(3 \times 50 \mathrm{~mL})$, the organic phase was recovered and concentrated in vacuo. The product $(1.38 \mathrm{~g}, 75 \%)$ was obtained as yellow oil, TLC (silica-gel, 20\% EtOAc/hexanes $\left.\mathrm{R}_{f}=0.55\right)$. Chromatographic purification $(2 \mathrm{x} 17 \mathrm{~cm}$ EtOAc/hexanes gradient). IR (KBr, cm $\left.{ }^{-1}\right) 2974$ (s), 2936 (s), 2877 (s), 1793 (s), 1794, (s), 1587 (s), 1098 (s) ; ${ }^{1} \mathrm{H} \mathrm{NMR}\left(\mathrm{CDCl}_{3}, 200 \mathrm{MHz}\right) \delta 5.39$ (hept, $\left.J=6.2 \mathrm{~Hz}, 1 \mathrm{H}\right), 2.99$ (hept, $J=7 \mathrm{~Hz}, 1$ $\mathrm{H}), 1.43(\mathrm{~d}, J=6.2 \mathrm{~Hz}, 6 \mathrm{H}), 1.27$ (d, $\left.J=7.3 \mathrm{~Hz}, 6 \mathrm{H}) ;{ }^{13} \mathrm{C} \mathrm{RMN} \mathrm{(CDCl} 3,200 \mathrm{MHz}\right) \delta 197.4$, $195.1,194.8,189.1,79.2,27.1,23.0,19.2 .^{26}$ 


\section{Rearrangement with $\mathrm{HCl}_{(\mathrm{aq})}$}

Isopropylmagnesium chloride $(9.25 \mathrm{~mL}$, of a $1.1 \mathrm{M}$ solution, $11.1 \mathrm{mmol})$ was added via syringe to $10 \mathrm{~mL}$ of a cold solution $\left(-78^{\circ} \mathrm{C}\right)$ of diisopropylsquarate $(2.0 \mathrm{~g}, 10.1 \mathrm{mmol}, 1.1 \mathrm{eq})$ in THF. After 20 min the reaction was quenched with $20 \mathrm{~mL}$ of an aq. saturated $\mathrm{NH}_{4} \mathrm{Cl}$ solution. The cooling bath was removed and the mixture was allowed to reach room temperature. It was then extracted with ether $(3 \times 30 \mathrm{~mL})$, dried over $\mathrm{MgSO}_{4}$ filtrated and concentrated in vacuo, to yield a white solid. This solid was redisolved in $25 \mathrm{~mL}$ of $\mathrm{CH}_{2} \mathrm{Cl}_{2}$ and added three drops of $\mathrm{HCl} 12 \mathrm{~N}$ with continuous stirring. After 5 min., TLC shows the completion of the reaction. Concentration of the crude reaction in vacuo and purification by column chromatography on silica-gel yielded a yellow oil $(1.7 \mathrm{~g}, 92 \%)$ corresponding to our desired compound.

\section{Representative addition of aryl lithium derivatives}

2-Isopropyl-3-isopropoxy-4-hydroxy-4-phenyl-2-cyclobutene-1-one (7). Phenyl-lithium $(5.49 \mathrm{~mL}$, of a $1.1 \mathrm{M}$ solution, $6.04 \mathrm{mmol})$ was added via syringe to $10 \mathrm{~mL}$ of a cold solution ($\left.78{ }^{\circ} \mathrm{C}\right)$ of dione $(2),(1.0 \mathrm{~g}, 5.49 \mathrm{mmol})$ in THF. After $5 \mathrm{~min}$., this solution was treated at the same temperature with $20 \mathrm{~mL}$ of aqueous $\mathrm{NH}_{4} \mathrm{Cl}$. The crude reaction mixture was extracted with ether $(3 \times 20 \mathrm{~mL})$, dried over $\mathrm{MgSO}_{4}$ and filtered. The solvent was removed in vacuo. The product ( $680 \mathrm{mg}, 48 \%$ ) was obtained as a white solid, TLC (silica-gel, 20\% EtOAc/hexanes $\mathrm{R}_{f}=$ 0.31). Chromatographic purification (silica-gel, $1.5 \times 15 \mathrm{~cm}$ EtOAc/hexanes), mp 90-92 ${ }^{\circ} \mathrm{C}$. Anal. Calcd. for $\mathrm{C}_{16} \mathrm{H}_{20} \mathrm{O}_{3} ; \mathrm{C}, 73.82 ; \mathrm{H}, 7.74$. Found: C, 73.70; H, 7.93. IR (KBr, cm $\left.{ }^{-1}\right) 3335$ (m), 2966 (m), $1744(\mathrm{~m}), 1610$ (s), 1100 (s) ; ${ }^{1} \mathrm{H}$ NMR $\left(\mathrm{CDCl}_{3}, 200 \mathrm{MHz}\right) \delta 7.49-7.24$ (m, $5 \mathrm{H}$ ), 4.65 (hept, $J=6.2 \mathrm{~Hz}, 1 \mathrm{H}), 4.23$ (bs, $1 \mathrm{H}), 2.60$ (hept, $J=7 \mathrm{~Hz}, 1 \mathrm{H}), 1.36(\mathrm{~d}, J=5.8 \mathrm{~Hz}, 3 \mathrm{H})$, $1.24(\mathrm{~d}, J=7.2 \mathrm{~Hz}, 3 \mathrm{H}), 1.23(\mathrm{~d}, J=7 \mathrm{~Hz}, 3 \mathrm{H}), 1.03(\mathrm{~d}, J=6.2 \mathrm{~Hz}, 3 \mathrm{H}) ;{ }^{13} \mathrm{C} \mathrm{RMN}\left(\mathrm{CDCl}_{3}, 200\right.$ $\mathrm{MHz}) \delta 190.4,180.7,137.6,134.5,128.0,125.7,92.8,78.1,24.2,23.0,22.6,20.7$. HRMS: $\mathrm{m} / z$ calcd. for $\mathrm{C}_{16} \mathrm{H}_{20} \mathrm{O}_{3}\left[\mathrm{MH}^{+}\right]$: 261.1491. Found: 261.1489 .

2-Isopropyl-3-isopropoxy-1,4-naphthoquinone (16). Bright yellow oil (74\%); $\left(\mathrm{R}_{f}=0.70,20 \%\right.$ EtOAc/hexanes). IR (KBr, cm $\left.{ }^{-1}\right)$ 2965, 2932, 2857 (m), 1668 (s), 1597 (s), 1259 (m); ${ }^{1} \mathrm{H}$ NMR $\left(\mathrm{CDCl}_{3}, 200 \mathrm{MHz}\right) \delta 7.98-7.86(\mathrm{~m}, 2 \mathrm{H}), \quad 7.63-7.51(\mathrm{~m}, 2 \mathrm{H}), \quad 5.01$ (hept, $\left.J=6.2 \mathrm{~Hz}, 1 \mathrm{H}\right), 3.39$ (hept, $J=6.9 \mathrm{~Hz}, 1 \mathrm{H}), 1.26(\mathrm{~d}, J=6.2 \mathrm{~Hz}, 6 \mathrm{H}), 1.22(\mathrm{~d}, J=6.9 \mathrm{~Hz}, 6 \mathrm{H}) ;{ }^{13} \mathrm{C} \mathrm{NMR}\left(\mathrm{CDCl}_{3}, 200\right.$ $\mathrm{MHz}) \delta 185.4,182.2,156.4,140.9,133.8,133.0,132.7,131.5,126.2,125.9,75.9,25.5,23.1$, 20.7. HRMS: $m / z$ calcd. for $\mathrm{C}_{16} \mathrm{H}_{19} \mathrm{O}_{3}\left[\mathrm{MH}^{+}\right]$: 259.1334. Found: 259.1331.

2-Hydroxy-3-isopropyl-1,4-naphthoquinone (25). Yellow solid (81\%); $\left(\mathrm{R}_{f}=0.56\right)(20 \%$ EtOAc/hexanes); mp 85-87 ${ }^{\circ} \mathrm{C}$, IR ( $\left.\mathrm{KBr}, \mathrm{cm}^{-1}\right) 3373$ (s), 2960 (m), 1655 (s), 1593 (m), 1256 (s); ${ }^{1} \mathrm{H}$ NMR $\left(\mathrm{CDCl}_{3}, 200 \mathrm{MHz}\right) \delta 8.01(\mathrm{dd}, J=1.4,10.8 \mathrm{~Hz} 1 \mathrm{H}), 8.05(\mathrm{dd}, J=1.4,10.5 \mathrm{~Hz}, 1 \mathrm{H})$, 7.73 (dt, $J=1.6,7.4 \mathrm{~Hz}, 6 \mathrm{H}), 7.64$ (dt, $J=1.4,7.3 \mathrm{~Hz}, 1 \mathrm{H}), 7.44$ (s, H), 3.41 (hept, $J=7 \mathrm{~Hz}, 1 \mathrm{H}$ ), $1.31(\mathrm{~d}, J=7.4 \mathrm{~Hz}, 6 \mathrm{H}) ;{ }^{13} \mathrm{C} \mathrm{NMR}\left(\mathrm{CDCl}_{3}, 200 \mathrm{MHz}\right) \delta 184.7,182.1,152.9,135.1,133.3$, $132.9,129.4,128.9,127.1,126.1,29.9,24.8,20.8 .^{27}$

2-Isopropyl-3-isopropoxy-4-hydroxy-4-tolyl-2-cyclobutene-1-one (8). White needles (23\%); $\left(\mathrm{R}_{f}=0.33\right)\left(20 \%\right.$ EtOAc/hexanes), mp $104-106^{\circ} \mathrm{C}$. Anal. Calcd. for $\mathrm{C}_{17} \mathrm{H}_{22} \mathrm{O}_{3} ; \mathrm{C}, 74.42 ; \mathrm{H}$, 8.08. Found: C, 74.40; H, 8.18. IR (KBr, cm $\left.{ }^{-1}\right) 3335$ (m), 2966(m), 1744 (s), 1602 (s), 1100 
(m); ${ }^{1} \mathrm{H} \mathrm{NMR}\left(\mathrm{CDCl}_{3}, 200 \mathrm{MHz}\right) \delta 7.35(\mathrm{~d}, J=7.8 \mathrm{~Hz}, 2 \mathrm{H}), 7.16(\mathrm{~d}, J=8.2 \mathrm{~Hz}, 2 \mathrm{H}), 4.66$ (hept, $J=6.2 \mathrm{~Hz}, 1 \mathrm{H}$ ), 4.45 (bs, 1H), 2.60 (hept, $J=7 \mathrm{~Hz}, 1 \mathrm{H}), 2.35$ (s, 3H), 1.36 (d, $J=6.2 \mathrm{~Hz}, 3 \mathrm{H}), 1.24$ $(\mathrm{d}, J=7 \mathrm{~Hz}, 3 \mathrm{H}) ; 1.23(\mathrm{~d}, J=7 \mathrm{~Hz}, 3 \mathrm{H}), 1.06(\mathrm{~d}, J=6.2 \mathrm{~Hz}, 3 \mathrm{H}) ;{ }^{13} \mathrm{C} \mathrm{NMR}\left(\mathrm{CDCl}_{3}, 200 \mathrm{MHz}\right) \delta$ $190.3,180.6$, 137.8, 134.6, 129.4, 125.6, 92.8, 77.9, 24.2, 23.0, 22.6, 21.3, 20.6. HRMS: $\mathrm{m} / z$ calcd. for $\mathrm{C}_{17} \mathrm{H}_{23} \mathrm{O}_{3}\left[\mathrm{MH}^{+}\right]$: 275.1647. Found: 275.1646 .

2-Isopropoxy-3-isopropyl-6-methyl-1,4-naphthoquinone (17). Bright yellow solid (72\%); $\left(\mathrm{R}_{f}\right.$ $=0.72)(20 \%$ EtOAc/hexanes $), \mathrm{mp} 84-86^{\circ} \mathrm{C}$. Anal. Calcd. for $\mathrm{C}_{17} \mathrm{H}_{20} \mathrm{O}_{3} ; \mathrm{C}, 74.97 ; \mathrm{H}, 7.40$. Found: C, 74.82 ; H, 7.60. IR (KBr, cm $\left.{ }^{-1}\right) 2966(\mathrm{~m}), 1660$ (s), 1650 (s), 1594 (s), $1258(\mathrm{~m})$; ${ }^{1} \mathrm{H}$ NMR $\left(\mathrm{CDCl}_{3}, 200 \mathrm{MHz}\right) \delta 7.87(\mathrm{~d}, J=7.8 \mathrm{~Hz}, 1 \mathrm{H}), 7.82(\mathrm{~d}, J=0.8 \mathrm{~Hz}, 1 \mathrm{H}), 7.43$ (dd, $J=0.7$, 8.1Hz, 1H), 5.09 (hept, $J=6.2 \mathrm{~Hz}, 1 \mathrm{H}$ ), 3.46 (hept, $J=7 \mathrm{~Hz}, 1 \mathrm{H}$ ), 2.45 (s, 3H), 1.34 (d, $J=6.2 \mathrm{~Hz}$, $6 \mathrm{H}), 1.30(\mathrm{~d}, J=7 \mathrm{~Hz}, 6 \mathrm{H}) ;{ }^{13} \mathrm{C} \mathrm{NMR}\left(\mathrm{CDCl}_{3}, 200 \mathrm{MHz}\right) \delta 185.8,182.2,156.5,144.9,140.7$, $133.7,132.7,129.3,126.7,126.3,75.9,25.5,23.1,22.0,20.7$. HRMS: $m / z$ calcd. for $\mathrm{C}_{17} \mathrm{H}_{20} \mathrm{O}_{3}$ $\left[\mathrm{MH}^{+}\right]: 273.1485$. Found: 273.1484 .

2-Hydroxy-3-isopropyl-6-methyl-1,4-naphthoquinone (26). Bright yellow solid (78\%); $\left(\mathrm{R}_{f}=\right.$ 0.64) (20\% EtOAc/hexanes), mp. $161-163{ }^{\circ} \mathrm{C}$. Anal. Calcd. for $\mathrm{C}_{14} \mathrm{H}_{14} \mathrm{O}_{3} ; \mathrm{C}, 73.03 ; \mathrm{H}, 6.13$. Found : C, 72.85 ; H, 6.38. IR (KBr, cm $\left.{ }^{-1}\right) 3328(\mathrm{~m}), 2960$ (m), 1654 (s), 1570 (s), 1270 (s); ${ }^{1} \mathrm{H}$ NMR $\left(\mathrm{CDCl}_{3}, 200 \mathrm{MHz}\right) \delta 7.94(\mathrm{~d}, J=7.8 \mathrm{~Hz}, 1 \mathrm{H}), 7.91(\mathrm{~d}, J=3.6 \mathrm{~Hz}, 1 \mathrm{H}), 7.47$ (s, 1H), 7.45 (d, $J=8.2 \mathrm{~Hz}, 1 \mathrm{H}), 3.40$ (hept, $J=6.8 \mathrm{~Hz}, 1 \mathrm{H}), 2.49$ (s, 3H), 1.30 (d, $J=7.2 \mathrm{~Hz}, 6 \mathrm{H}) ;{ }^{13} \mathrm{C}$ NMR $\left(\mathrm{CDCl}_{3}, 200 \mathrm{MHz}\right) \delta 185.0,181.5,153.0,146.6,133.5,133.3,128.5,127.6,127.1,126.4$, 24.8, 22.3, 20.0. HRMS: $m / z$ calc. for $\mathrm{C}_{14} \mathrm{H}_{15} \mathrm{O}_{3}\left[\mathrm{MH}^{+}\right]$: 231.1021. Found: 231.1019 .

2-Isopropyl-3-isopropoxy-4-hydroxy-4- $p$-methoxyphenyl-2-cyclobutene-1-one (9). White crystals $(63 \%)\left(\mathrm{R}_{f}=0.23\right)(20 \%$ EtOAc/hexanes $), \mathrm{mp} 113-115{ }^{\circ} \mathrm{C}$. Anal. Calcd. for $\mathrm{C}_{17} \mathrm{H}_{22} \mathrm{O}_{4} ; \mathrm{C}$, 70.32 ; H, 7.64. Found: C, 70.20; H, 7.80. IR (KBr, cm $\left.{ }^{-1}\right) 3334$ (m), 2966, 2934 (m), 1743 (s), 1607 (s), 1252 (s), 1100 (s); ${ }^{1} \mathrm{H} \mathrm{NMR}\left(\mathrm{CDCl}_{3}, 200 \mathrm{MHz}\right) \delta 7.37$ (d, J=8.8 Hz, 2H), 6.88 (d, $J=8.4 \mathrm{~Hz}, 2 \mathrm{H}$ ), 4.67 (hept, $J=6.2 \mathrm{~Hz}, 1 \mathrm{H}$ ), 4.31 (bs, 1H), 3.81 (s, 3H), 2.58 (hept, $J=7 \mathrm{~Hz}$, $1 \mathrm{H}), 1.35$ (d, $J=5.8 \mathrm{~Hz}, 3 \mathrm{H}), 1.23$ (d, $J=6.8 \mathrm{~Hz}, 3 \mathrm{H}), 1.22$ (d, $J=6.8 \mathrm{~Hz}, 3 \mathrm{H}), 1.05$ (d, $J=6.4 \mathrm{~Hz}$, $6 \mathrm{H}) ;{ }^{13} \mathrm{C} \mathrm{NMR}\left(\mathrm{CDCl}_{3}, 200 \mathrm{MHz}\right) \delta 190.7,180.9,159.5,134.3,129.7,126.9,114.1,92.5,77.9$, 55.4, 24.2, 23.0, 22.7, 20.7. HRMS: $m / z$ calcd. for $\mathrm{C}_{17} \mathrm{H}_{23} \mathrm{O}_{4}\left[\mathrm{MH}^{+}\right]$: 291.1596. Found: 291.1595 .

2-Isopropoxy-3-isopropyl-6-methoxy-1,4-naphthoquinone (18). Bright yellow solid (71\%); $\left(\mathrm{R}_{f}=0.62\right)(20 \% \mathrm{EtOAc} /$ hexanes $), \mathrm{mp} 81-83{ }^{\circ} \mathrm{C}$. Anal. Calcd. for $\mathrm{C}_{17} \mathrm{H}_{20} \mathrm{O}_{4} ; \mathrm{C}, 70.81 ; \mathrm{H}, 6.99$. Found: C, 70.60; H, 7.28. IR (KBr, cm $\left.{ }^{-1}\right) 2964$ (m), 1666 (s), 1589 (s), 1236 (s); ${ }^{1} \mathrm{H}$ NMR $\left(\mathrm{CDCl}_{3}, 200 \mathrm{MHz}\right) \delta 7.94(\mathrm{~d}, J=8.4 \mathrm{~Hz}, 1 \mathrm{H}), 7.49(\mathrm{~d}, J=2.8 \mathrm{~Hz}, 1 \mathrm{H}), 7.11(\mathrm{dd}, J=2.6,8.4 \mathrm{~Hz}$, 1H), 5.11 (hept, $J=6.2 \mathrm{~Hz}, 1 \mathrm{H}$ ), 3.92 (s, 3H), 3.46 (hept, $J=7 \mathrm{~Hz}, 1 \mathrm{H}$ ), 1.35 (d, $J=6 \mathrm{~Hz}, 6 \mathrm{H}$ ), $1.30(\mathrm{~d}, J=7 \mathrm{~Hz}, 6 \mathrm{H}) ;{ }^{13} \mathrm{C} \mathrm{NMR}\left(\mathrm{CDCl}_{3}, 200 \mathrm{MHz}\right) \delta 185.5,181.4,164.3,156.7,140.5,135.0$, $128.5,125.1,119.8,109.7,76.0,56.0,25.6,23.2,20.7$. HRMS: m/z calcd. for $\mathrm{C}_{17} \mathrm{H}_{21} \mathrm{O}_{4}\left[\mathrm{MH}^{+}\right]$: 289.1440. Found: 289.1439.

2-Hydroxy-3-isopropyl-6-methoxy-1,4-naphthoquinone (27). Bright yellow solid (81\%); $\left(\mathrm{R}_{f}\right.$ $=0.51) 20 \%$ EtOAc/hexanes), mp 85-87 ${ }^{\circ} \mathrm{C}$. Anal. Calcd. for $\mathrm{C}_{14} \mathrm{H}_{14} \mathrm{O}_{4} ; \mathrm{C}, 68.28$; H, 5.73. Found: C, 68.15; H, 5.97. IR (KBr, cm $\left.{ }^{-1}\right) 3337$ (m), 2965 (m), 1685 (s), 1594 (s), 1233 (s); ${ }^{1} \mathrm{H}$ 
NMR $\left(\mathrm{CDCl}_{3}, 200 \mathrm{MHz}\right) \delta 7.98(\mathrm{~d}, J=8.4 \mathrm{~Hz}, 1 \mathrm{H}), 7.59(\mathrm{~s}, 1 \mathrm{H}), 7.55(\mathrm{~d}, J=2.6 \mathrm{~Hz}, 1 \mathrm{H}), 7.09$ $(\mathrm{dd}, J=2.4,8.2 \mathrm{~Hz}, 1 \mathrm{H}), 3.94(\mathrm{~s}, 3 \mathrm{H}), 3.38$ (hept, $J=7 \mathrm{~Hz}, 1 \mathrm{H}), 1.29(\mathrm{~d}, J=7 \mid \mathrm{Hz}, 6 \mathrm{H})$; ${ }^{13} \mathrm{C}$ NMR $\left(\mathrm{CDCl}_{3}, 200 \mathrm{MHz}\right) \delta 184.6,180.7,165.4,153.2,135.9,128.8,128.0,122.6,119.1,111.0$, 56.1, 24.8, 20.0. HRMS: $\mathrm{m} / z$ calcd. for $\mathrm{C}_{14} \mathrm{H}_{15} \mathrm{O}_{4}\left[\mathrm{MH}^{+}\right]: 247.0970$. Found: 247.0968 .

3-Ethyl-4 -isopropoxy-3-cyclobutene-1,2-dione (23). Yellow oil (92\%); $\left(\mathrm{R}_{\boldsymbol{f}}=0.51\right)(20 \%$ EtOAc/hexanes). IR (KBr, cm $\left.{ }^{-1}\right) 2983(\mathrm{~m}), 1788(\mathrm{~m}), 1759(\mathrm{~m}), 1658(\mathrm{~m}), 1098(\mathrm{~m}) ;{ }^{1} \mathrm{H}$ NMR $\left(\mathrm{CDCl}_{3}, 200 \mathrm{MHz}\right) \delta 5.37$ (hept, $\left.J=6.2 \mathrm{~Hz}, 1 \mathrm{H}\right), 2.60$ (q, $\left.J=7.6 \mathrm{~Hz}, 2 \mathrm{H}\right), 1.43(\mathrm{~d}, J=6.2 \mathrm{~Hz}, 6 \mathrm{H})$, $1.235(\mathrm{t}, J=7.7 \mathrm{~Hz}, 3 \mathrm{H}) ;{ }^{13} \mathrm{C} \mathrm{NMR}\left(\mathrm{CDCl}_{3} 200 \mathrm{MHz}\right) \delta 198.4,196.1,194.1,185.4,79.4,22.9$, $18.7,10.1 .^{28}$

2-Ethyl-3-isopropoxy-4-hydroxy-4-phenyl-2-cyclobutene-1-one (10). Yellow oil (42\%); $\left(\mathrm{R}_{f}=\right.$ 0.17) (20\% EtOAc/hexanes). IR (KBr, cm $\left.{ }^{-1}\right) 3345$ (m), 2979 (m), 2935 (m), 1746 (m), 1608 (s), $1100(\mathrm{~m}) ;{ }^{1} \mathrm{H}$ NMR $\left(\mathrm{CDCl}_{3}, 200 \mathrm{MHz}\right) \delta$ 7.51-7.45 (m, 2H), 7.41-7.29 (m, 2H), 4.69 (hept, $J=6.2 \mathrm{~Hz}, 1 \mathrm{H}), 2.20$ (q, $J=7.6 \mathrm{~Hz}, 2 \mathrm{H}), 1.37$ (d, $J=6.2 \mathrm{~Hz}, 3 \mathrm{H}), 1.18$ (t, $J=7.7 \mathrm{~Hz}, 3 \mathrm{H}), 1.11$ (d, $J=6.2 \mathrm{~Hz}, 3 \mathrm{H}) ;{ }^{13} \mathrm{C} \mathrm{NMR}\left(\mathrm{CDCl}_{3}, 200 \mathrm{MHz}\right) \delta 190.9,181.2,137.4,130.2,128.7,128.2,125.7$, 92.7, 77.9, 22.9, 22.5, 15.8, 12.1. HRMS: $m / z$ calcd. for $\mathrm{C}_{15} \mathrm{H}_{19} \mathrm{O}_{3}\left[\mathrm{MH}^{+}\right]$: 247.1334. Found: 247.1333.

2-Ethyl-3-isopropoxy-1,4-naphthoquinone (19). Orange oil (75\%), ; $\quad\left(\mathrm{R}_{f}=0.73\right) \quad(20 \%$ EtOAc/hexanes). IR (KBr cm $\left.{ }^{-1}\right) 2975(\mathrm{~m}), 2935$ (m), 1654 (m), 1603 (m), 1243 (m); ${ }^{1} \mathrm{HNMR}$ $\left(\mathrm{CDCl}_{3}, 200 \mathrm{MHz}\right) \delta 8.06-7.98(\mathrm{~m}, 2 \mathrm{H}), 7.71-761(\mathrm{~m}, 2 \mathrm{H}), 5.08$ (hept, $\left.J=6.2 \mathrm{~Hz}, 1 \mathrm{H}\right), 2.61$ (q, $J=7.5 \mathrm{~Hz}, 2 \mathrm{H}), 1.34(\mathrm{~d}, J=5.8 \mathrm{~Hz}, 6 \mathrm{H}), 1.10(\mathrm{t}, J=7.5 \mathrm{~Hz}, 3 \mathrm{H}) ;{ }^{13} \mathrm{C} \mathrm{NMR}\left(\mathrm{CDCl}_{3}, 200 \mathrm{MHz}\right) \delta$ $185.4,182.1,156.5,138.4,133.8,133.2,132.4,131.8,126.3,75.9,23.2,17.5,13.3$. HRMS: $m / z$ calcd. for $\mathrm{C}_{15} \mathrm{H}_{17} \mathrm{O}_{3}\left[\mathrm{MH}^{+}\right]: 245.1178$. Found: 245.1177 .

2-Hydroxy-3-ethyl-1,4-naphthoquinone (28). Yellow solid (81\%); $\quad\left(\mathrm{R}_{f}=0.53\right) \quad(20 \%$ EtOAc/hexanes); mp 136-138 ${ }^{\circ} \mathrm{C}$. IR (KBr, cm $\left.{ }^{-1}\right) 3329$ (m), 2967 (m), 1664 (s), 1638 (s), 1250 (m), 1089 (s); ${ }^{1} \mathrm{H} \mathrm{NMR}\left(\mathrm{CDCl}_{3}, 200 \mathrm{MHz}\right) \delta 8.13$ (dd, $\left.J=1.1,9.8 \mathrm{~Hz}, 1 \mathrm{H}\right), 8.09$ (dd, $J=1.4,9.4$ $\mathrm{Hz}, 1 \mathrm{H}), 7.77$ (dt, $J=1.5,7.2 \mathrm{~Hz}, 1 \mathrm{H}), 7.68$ (d, $J=1.6,7.5 \mathrm{~Hz}, 1 \mathrm{H}), 7.31(\mathrm{~s}, 1 \mathrm{H}), 2.64$ (q, $J=7.5$ $\mathrm{Hz}, 2 \mathrm{H}), 1.16(\mathrm{t}, J=7.5 \mathrm{~Hz}, 3 \mathrm{H}) ;{ }^{13} \mathrm{C} \mathrm{NMR}\left(\mathrm{CDCl}_{3}, 200 \mathrm{MHz}\right) \delta 184.8,181.8,152.9,135.0$, $133.2,133.1,129.6,127.0,126.3,126.1,16.9,12.9 .^{29}$

2-Ethyl-3-isopropoxy-4-hydroxy-4-tolyl-2-cyclobutene-1-one (11). White crystals (42\%); $\left(\mathrm{R}_{f}\right.$ $=0.21)(20 \%$ EtOAc/hexanes $), \mathrm{mp} 98-100{ }^{\circ} \mathrm{C}$. Anal. Calcd. for $\mathrm{C}_{16} \mathrm{H}_{20} \mathrm{O}_{3} ; \mathrm{C}, 73.82 ; \mathrm{H}, 7.74$. Found: C, 73.80; H, 7.97. IR (KBr, cm $\left.{ }^{-1}\right) 3310(\mathrm{~m}), 2978(\mathrm{~m}), 2938(\mathrm{~m}), 1748$ (m), 1603 (s), $1100(\mathrm{~m}) ;{ }^{1} \mathrm{H} \mathrm{NMR}\left(\mathrm{CDCl}_{3}, 200 \mathrm{MHz}\right) \delta 7.37$ (d, J=8.2 Hz, 2H), 7.18 (d, J=8 Hz, 2H), 4.69 (hept, $J=6.2 \mathrm{~Hz}, 1 \mathrm{H}), 2.35$ (s, 3H), 2.21 (q, $J=7.6 \mathrm{~Hz}, 2 \mathrm{H}), 1.39$ (d, $J=5.8 \mathrm{~Hz}, 3 \mathrm{H}), 1.18$ (t, $J=7.5 \mathrm{~Hz}, 3 \mathrm{H}), 1.17$ (d, $J=6.2 \mathrm{~Hz}, 3 \mathrm{H}) ;{ }^{13} \mathrm{C} \mathrm{NMR}\left(\mathrm{CDCl}_{3}, 200 \mathrm{MHz}\right) \delta 190.4,180.6,138.1$, $134.2,130.2,129.5,125.6,92.7,22.9,22.6,21.4,16.0,12.2$. HRMS: $m / z$ calcd. For $\mathrm{C}_{16} \mathrm{H}_{21} \mathrm{O}_{3}$ $\left[\mathrm{MH}^{+}\right]: 261.1490$. Found: 261.1488 .

2-Isopropoxy-3-ethyl-6-methyl-1,4-naphthoquinone (20). Bright yellow solid (75\%); ( $\mathrm{R}_{f}$

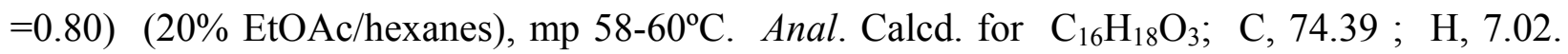
Found: C, 74.22 ; H, 7.37. IR (KBr, cm $\left.{ }^{-1}\right) 2974(\mathrm{~m}), 1662$ (s), 1597 (s), 1258 (s); ${ }^{1} \mathrm{H}$ NMR $\delta$ 7.46 (d, $J=7.3 \mathrm{~Hz}, 1 \mathrm{H}), 7.93$ (s, 1H), 7.87 (d, $J=7.2 \mathrm{~Hz}, 1 \mathrm{H}), 5.08$ (hept, $J=6.2 \mathrm{~Hz}, 1 \mathrm{H}), 2.61$ (q, 
$J=7.4 \mathrm{~Hz}, 2 \mathrm{H}), 2.47(\mathrm{~s}, 3 \mathrm{H}), 1.35(\mathrm{~d}, J=6 \mathrm{~Hz}, 6 \mathrm{H}), 1.10(\mathrm{t}, J=7.6 \mathrm{~Hz}, 3 \mathrm{H}) ;{ }^{13} \mathrm{C} \mathrm{NMR}\left(\mathrm{CDCl}_{3}\right.$, $200 \mathrm{MHz}) \delta 185.4,182.0,156.5,144.9,138.2,133.9,132.3,129.5,126.7,126.5,75.9,23.3$, 22.0, 17.5, 13.4. HRMS: $m / z$ calcd. for $\mathrm{C}_{16} \mathrm{H}_{19} \mathrm{O}_{3}\left[\mathrm{MH}^{+}\right]$: 259.1334. Found: 259.1333 .

2-Hydroxy-3-ethyl-6-methyl-1,4-naphthoquinone (29). Gold needles $(91 \%) ;\left(\mathrm{R}_{f}=0.57\right)(20 \%$ EtOAc/hexanes), mp 140-142 ${ }^{\circ} \mathrm{C}$. Anal. Calc. for $\mathrm{C}_{13} \mathrm{H}_{12} \mathrm{O}_{3} ; \mathrm{C}, 72.21 ; \mathrm{H}, 5.59$. Found: $\mathrm{C}$, 72.09; H, 5.87. IR (KBr, cm $\left.{ }^{-1}\right) 3353$ (m), 2967 (m), 1639 (m), 1595 (m), 1258 (m); ${ }^{1} \mathrm{H}$ NMR $\left(\mathrm{CDCl}_{3}, 200 \mathrm{MHz}\right) \delta 7.96(\mathrm{~d}, J=8 \mathrm{~Hz}, 1 \mathrm{H}), 7.92(\mathrm{bs}, 1 \mathrm{H}), 7.46(\mathrm{~d}, J=8.1 \mathrm{~Hz}, 1 \mathrm{H}), 7.35$ (bs, $\left.1 \mathrm{H}\right)$, 2.59 (q, $J=7.4 \mathrm{~Hz}, 2 \mathrm{H}), 2.47(\mathrm{~s}, 3 \mathrm{H}), 1.12(\mathrm{t} ; J=7.5 \mathrm{~Hz}, 3 \mathrm{H}) ;{ }^{13} \mathrm{C} \mathrm{NMR}\left(\mathrm{CDCl}_{3}, 200 \mathrm{MHz}\right) \delta$ 185.1, 181.5, 153.0, 146.5, 133.6, 133.1, 127.5, 127.3, 126.5, 125.7, 22.3, 16.9, 12.9. HRMS: $m / z$ calcd. for $\mathrm{C}_{13} \mathrm{H}_{13} \mathrm{O}_{3}\left[\mathrm{MH}^{+}\right]$: 217.0865. Found: 217.0865 .

2-Ethyl-3-isopropoxy-4-hydroxy-4-p-methoxyphenyl-2-cyclobutene-1-one(12). White crystals $(44 \%)\left(\mathrm{R}_{f}=0.12\right)\left(20 \%\right.$ EtOAc/hexanes), mp 83-85 ${ }^{\circ} \mathrm{C}$. Anal. Calcd. for $\mathrm{C}_{16} \mathrm{H}_{20} \mathrm{O}_{4} ; \mathrm{C}$, 69.54; H, 7.30. Found: C, 69.23; H, 7.55. IR (KBr, cm $\left.{ }^{-1}\right) 3322(\mathrm{~m}), 2978(\mathrm{~m}), 1744(\mathrm{~m}), 1654$ (s), 1255 (s), 1098 (s); ${ }^{1} \mathrm{H}$ NMR (CDCl, $\left.200 \mathrm{MHz}\right) \delta 7.40$ (d, $\left.J=8.4 \mathrm{~Hz}, 2 \mathrm{H}\right), 6.89$ (d, $J=8.8 \mathrm{~Hz}$, 2H), 4.71 (hept, $J=6.3 \mathrm{~Hz}, 1 \mathrm{H}), 3.9$ (bs, $1 \mathrm{H}), 3.81$ (s, 3H), 2.19 (q, $J=7.6 \mathrm{~Hz}, 2 \mathrm{H}), 1.38$ (d, $J=6.2 \mathrm{~Hz}, 3 \mathrm{H}), 1.18(\mathrm{t}, J=7.7 \mathrm{~Hz}, 3 \mathrm{H}), 1.15(\mathrm{~d}, J=6 \mathrm{~Hz}, 3 \mathrm{H}) ;{ }^{13} \mathrm{C} \mathrm{NMR}\left(\mathrm{CDCl}_{3}, 200 \mathrm{MHz}\right) \delta$ 191.1, 181.2, 159.6, 130.0, 129.5, 122.1, 114.1, 92.4, 55.5, 22.9, 22.6, 15.9, 12.1. HRMS: $\mathrm{m} / \mathrm{z}$ calcd. for $\mathrm{C}_{16} \mathrm{H}_{21} \mathrm{O}_{4}\left[\mathrm{MH}^{+}\right]: 277.1440$. Found: 277.1439.

2-Isopropoxy-3-ethyl-6-methoxy-1,4-naphthoquinone (21). Yellow solid $(70 \%)$; $\left(\mathrm{R}_{f}=0.56\right)$ (20\% EtOAc/hexanes), mp 55-57 ${ }^{\circ} \mathrm{C}$. Anal. Calcd. for $\mathrm{C}_{16} \mathrm{H}_{18} \mathrm{O}_{4} ; \mathrm{C}, 70.06 ; \mathrm{H}, 6.61$. Found : C, 69.85 ; H, 6.92. IR (KBr, cm $\left.{ }^{-1}\right) 2980$ (m), 1735, 1718 (s); 1689, 1647, 1595 (s), 1260, 1239, 210 (s), 1107 (s); ${ }^{1} \mathrm{H}$ NMR $\left(\mathrm{CDCl}_{3}, 200 \mathrm{MHz}\right) \delta 7.94$ (dd, $\left.J=1.0,8.7 \mathrm{~Hz}, 1 \mathrm{H}\right), 7.48$ (dd, $J=1.2$, $3.0 \mathrm{~Hz}, 1 \mathrm{H}$ ), 7.10 (dd, $J=2.8,8.7 \mathrm{~Hz}, 1 \mathrm{H}), 5.09$ (hept, $J=6.2 \mathrm{~Hz}, 1 \mathrm{H}), 3.92$ (s, 3H), 2.59 (q, $J=7.6 \mathrm{~Hz}, 2 \mathrm{H}), 1.34(\mathrm{~d}, J=6.2 \mathrm{~Hz}, 6 \mathrm{H}), 1.09(\mathrm{t}, J=7.5 \mathrm{~Hz}, 3 \mathrm{H}) ;{ }^{13} \mathrm{C} \mathrm{NMR}\left(\mathrm{CDCl}_{3}, 200 \mathrm{MHz}\right)$ $\delta 185.5,181.1,164.2,156.7,137.8,134.5,128.7,125.2,119.6,109.8,76.0,56.0,23.2,17.5$, 13.3. HRMS: $m / z$ calcd. for $\mathrm{C}_{16} \mathrm{H}_{19} \mathrm{O}_{4}\left[\mathrm{MH}^{+}\right]$: 275.1283 . Found: 275.1280 .

2-Hydroxy-3-ethyl-6-methoxy-1,4-naphthoquinone (30). Yellow solid (79\%); $\left(\mathrm{R}_{f}=0.45\right)$ (20\% EtOAc/hexanes), mp 128-130 ${ }^{\circ} \mathrm{C}$. Anal. Calcd. for $\mathrm{C}_{13} \mathrm{H}_{12} \mathrm{O}_{4} ; \mathrm{C}, 67.23 ; \mathrm{H}, 5.21$. Found : C, 67.15; H, 5.55. IR (KBr, cm $\left.{ }^{-1}\right) 3342$ (s), 2965 (m), 1642 (s), 1587 (s), 1242 (s); ${ }^{1} \mathrm{H}$ NMR $\left(\mathrm{CDCl}_{3}, 200 \mathrm{MHz}\right) \delta 8.01(\mathrm{~d}, J=8.4 \mathrm{~Hz}, 1 \mathrm{H}), 7.58(\mathrm{~d}, J=3 \mathrm{~Hz}, 1 \mathrm{H}), 7.44(\mathrm{bs}, 1 \mathrm{H}), 7.11(\mathrm{dd}$, $J=2.3,8.2 \mathrm{~Hz}, 1 \mathrm{H}), 3.95$ (s, 3H), 2.60 (q, $J=7.4 \mathrm{~Hz}, 2 \mathrm{H}), 1.14(\mathrm{t}, J=7.5 \mathrm{~Hz}, 3 \mathrm{H}) ;{ }^{13} \mathrm{C}$ NMR $\left(\mathrm{CDCl}_{3} 200 \mathrm{MHz}\right) 184.7,180.5,165.4,153.2,135.7,128.9,125.2,122.8,119.2,111.0,56.2$, 16.9, 12.9. HRMS: $m / z$ calcd. for $\mathrm{C}_{13} \mathrm{H}_{13} \mathrm{O}_{4}\left[\mathrm{MH}^{+}\right]$: 233.0814. Found: 233.0813 .

\section{Electrochemical studies}

All the experiments corresponding to cyclic voltammetry were recorded in a Electrochemical Analyser BAS-100 with a typical three electrodes arrangement. $\mathrm{Ag} / \mathrm{AgCl}, 7 \mathrm{~mm}^{2}$ glassy carbon and platinum as reference, working and auxiliary electrodes respectively. Dry acetonitrile was used as solvent which was dried over anhydrous $\mathrm{CaCl}_{2}$, and distilled from $\mathrm{CaH}_{2}$. Dry tetrabutylammonium hexafluorophosphate was used as support electrolyte, which was dried by 
heating it to $60{ }^{\circ} \mathrm{C}$ under high vacuum for $6 \mathrm{~h}$. All the samples were prepared $2 \mathrm{mM}$ of quinone and $0.1 \mathrm{M}$ of ammonium salt concentration, and deoxygenated by bubbling nitrogen for $5 \mathrm{~min}$.

\section{Biological experimentation}

All the gametes (ovules and spermatozoids) were obtained form female or male Strongylocentrotus purpuratus by apply $1 \mathrm{~mL}$ of $0.5 \mathrm{M} \mathrm{KCl}$ besides genital zone. The ovules were kept directly on artificial sea water (ASW). All the experiments were carried out in artificial sea water prepared form commercially available Instant Ocean salts. Ovules and spermatozoids are in good conditions for experimentation for no more than three days.

Each experiment was adjusted to a $200 \mu \mathrm{L}$ of total volume in the next proportions; volume containing 2000 ovules $+1 \mu \mathrm{L}$ of sperm (1:32) $+1 \mu \mathrm{L}$ of drug dissolved in DMSO and the rest to complete $200 \mu \mathrm{L}$ was added ASW pH 8.0. The solvent for dissolve the drugs and used it as control is DMSO. The experiments were carried out in a multi excavated plaque, at $16{ }^{\circ} \mathrm{C}$ in a cool water bath. Periodic observation in $40 \mathrm{X}$ optic microscope, at $5 \mathrm{~min}$, and 90 min must be done.

\section{Acknowledgements}

Funding from the University of Guanajuato is greatly appreciated. C.R.S-A wishes to thank the University of Guanajuato for a scholarship. Funding from CONACYT Grant SEP-2004-C0145970/A1 is also appreciated.

\section{References}

1. Thomson, R. H.; Naturally Occurring Quinones; Academic: London; 1971.

2. Bramhmia, O.; Richard, C. Photochem. Photobiol Sci. 2003, 10, 1038.

3. Xu, L. X.; Shen, Y. X.; Wang, H. Y.; Jiang, J. G., Xiao, Y. Spectrochim. Acta A Mol Biomol. Spectrosc. 2003, 13, 3103.

4. Brinkworth, R. I.; Fairlie, D. P. Biochim. Biophys. Acta 1995, 1253, 5.

5. Fesen, M. R.; Kohn, K. W.; Leteurtre, F.; Pommier, Y. Proc. Natl. Acad. Sci. USA 1993, 90, 2399.

6. Ting, C. Y.; Hsu, C. T.; Hsu, H. T.; Su, J. S.; Chen, T. Y.; Tarn, W. Y.; Kuo, Y. H.; WangPeng, J.; Liu L. F.; Hwang, J. Biochem. Pharmacol. 2003, 66, 1981.

7. Alves, T. M.; Kloos, H.; Zani, C. L. Mem. Inst. Oswaldo Cruz 2003, 98, 709.

8. Aviv, N. S.; Bekhit, A. A.; Park, J. Y. Boll. Chim. Farm. 2003, 142, 232.

9. Caygill, G. B.; David, S. L.; Broker, S. J. Org. Chem. 2001, 66, 7427.

10. Pinto, A. V.; Pinto, C. N.; Pinto, Mdo. C.; Rita, R. S.; Pezzella, C. A.; de Castro, S. L. Arzneimittelforschung 1997, 47, 74. 
11. Mäntylä, A.; Garnier, T.; Rautio, J.; Nevalainen, T.; Vepsälainen, J.; Koskinen, A.; Croft, S.L.; Järvinen, T. J. Med. Chem. 2004, 47, 188.

12. Scheme da-Hirschmann, G.; Papastergiou, F. Z. Naturforsch 2003, 58, 495.

13. Couladouros, E. A.; Plyta, Z. F.; Strogilos, A. T.; Papageorgiou, P. V. Tetrahedron Lett. 1997, 38, 7263.

14. Chen, X.; Yang, L.; Zhang, N.; Turpin, J. A.; Buckheit, R. W.; Osterling, C.; Ppenheim, J. J.; Howard, O. M. Antimicrob. Agents Chemother. 2003, 47, 2810.

15. Nicolaou, K. C.; Gray, D. L. F. J. Am. Chem. Soc. 2004, 126, 607.

16. Harrity, J. P. A.; Kerr, W. J.; Middlemiss, D.; Soctt, J. S. J. Organomet. Chem. 1997, 532, 219.

17. (a) Petrova, S. A.; Kolodyazhny, M. V.: Ksenzhek, O. S. J. Electroanal. Chem. 1990, 277, 189. (b) González, F. J. Electroanalysis, 1998, 10, 638. (c) Ashnagar, A.; Bruce, J.; Dutton, P.; Prince, R. C. Biochim. Biophys. Acta 1984, 801, 351. (d) Crawford, P. W.; Carlos, E.; Ellegood, J. C.; Cheng, C. C.; Dong, Q.; Liu, D. F.; Luo, Y. L. Electrochim. Acta, 1996, 41, 2399.

18. (a) Lin, A. J.; Sartorelli, A. C. Biochemical Pharmacology 1976, 25, 206. (b) Cheng, Z.; Cheng, C. C. J. Med. Chem. 1978, 21, 291.

19. (a) Moore, H. W.; Yerxa, B. R. In Synthetic Utility of Cyclobutenediones; Halton, B.; Ed.; JAI Press: Greenwich, CT, 1995; Vol. 4, pp 81-162. (b) Liebeskind, L. S. Tetrahedron Symp. Print 1989, 45, 3053. (c) Koo, S.; Liebeskind, L. S. J. Am. Chem. Soc. 1995, 117, 3389. (d) Sun, L.; Liebeskind, L. S. J. Am. Chem. Soc. 1996, 118, 12473.

20. Solorio-Alvarado, C. R.; Rodríguez-Cendejas, C. G.; Peña-Cabrera. E. ARKIVOC 2003, (xi), 172.

21. Solorio-Alvarado, C. R.; Alvarez-Toledano. C.; Peña-Cabrera. E. ARKIVOC 2004, (i), 64.

22. (a) Aguilar-Martínez, M.; Macías-Ruvalcaba, N. A.; Bautista-Martínez, J. A.; Gómez, M.; González, F. J.; González, I. Curr. Org. Chem. 2004, 8, 1721. (b) Brillas, E.; Farnia, G.; Severin, M. G.; Vianello, E. Electrochimica Acta 1986, 31, 759. (c) Amatore, C.; Pinson, J.; Saveant, J. M. J. Electroanal. Chem. and Inter. Electrochem. 1982, 137, 143.

23. González, F. J. Electroanalysis 1998, 10, 638.

24. Frontana C.; Frontana, B. A.; González, I. J. Electroanal. Chem. 2004, 573, 307.

25. Cuellar-Mata, P.; Martínez-Cadena, G.; López-Godinez, J.; Obregón, A.; García-Soto, J. Eur. J. Cell Biol. 2000, 2, 81.

26. Pirrung, M. C.; Han, H.; Ludwing, R. T. J. Org. Chem. 1994, 59, 2430.

27. Turnbull, J. D.; Biagi, G. L.; Merola, A. J.; Cornwell, D. G. Biochem. Pharm. 1971, 20, 1383.

28. Peña-Cabrera, E.; Liebeskind, L. S. J. Org. Chem. 2002, 67, 1689.

29. Jewess, P. J.; Chamberlain, K.; Boogaard, A. B.; Devonshire, A. L.; Khambay, B. P. S. Pest. Manag. Science 2002, 58, 243. 